\title{
A Systematic Review and Meta-Analysis of Treatment of Infected Tibial non Union
}

\author{
Gamal A. Hosny, Mohamed A. Moselhy, Adel S. ElHamady, Peter M. Zaky Abadir
}

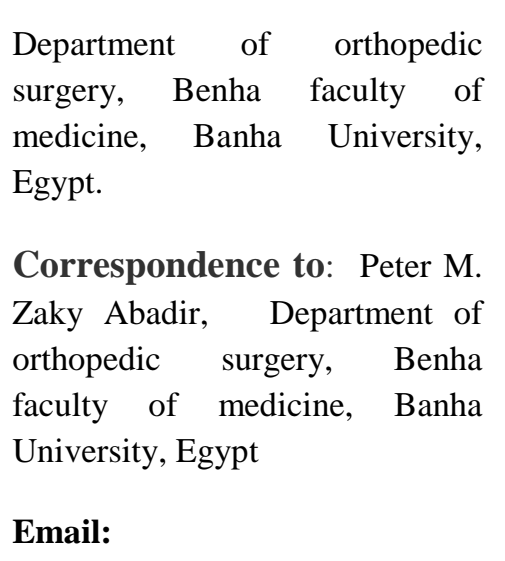

peter.abadir2018@gmail.com

Received: 8 March 2021

Accepted: 6 April 2021

\begin{abstract}
:
The aim of this work is to systematically review and make metaanalysis for treatment of the infected non-union of the tibia. A systematic review was completed, Study objective and comprehensive literature search were performed from the SCI, PubMed, Cochrane Library; and Embase between January 2000 and Feb. 2019. Some major data were statistically analyzed, including number of patients, mean age,external fixation time, Searches will be performed in the MEDLINE, Life Science Citations, PubMed, GoogleScholar and EMBASE Biochemical (http://www.embase.com) databases will be accessed to search studies with no limits set during research, Terms aimed at capturing the target diagnosis, such as "infected tibial nonunion" and "fixation" were combined using the Boolean operator "or" and MeSH terms. 318 abstracts were identified during the search, 10 were excluded, 308 full articles were fully reviewed, 295 articles
\end{abstract} additional articles were identified during searching, a total 652 patients of 15 studies were presented in this systemic review. It is concluded that radical debridment of the infected non union is mandatory, a satisfactory bone results and functional results were obtained. On the other hand Ilizaov technique proved as the most useful method in the treatment of the infected nonunion of the tibia.

Keywords: tibial, nonunion, infected, Ilizarov. 


\section{Introduction:}

Tibial shaft non-union is considered the commonest type of long bone non-union, the aetiological factors are due to high incidence of severe open fractures, high energy trauma associated with vascular and soft tissue compromise,infection and bone devitalization and segmental bone loss. (1-5) In this review, analysis of the different methods for the treatment of the infected non-union of the tibia and the results to find the most successful technique with a satisfactory outcome.

\section{Subjects and methods}

Type of study is asystemic review and meta analysis.Study objective and comprehensive literature search were performed from the SCI, PubMed, Cochrane Library; and Embase between January 2000 and Feb. 2019. Some major data were statistically analysed, including number of patients, mean age,external fixation time, Searches will be performed in the MEDLINE, Life Science Citations, PubMed, GoogleScholar and EMBASE Biochemical (http://www.embase.com/) databases will be accessed to search studies with no limits set during research, Terms aimed at capturing the target diagnosis, such as "infected tibial nonunion" and "fixation" were combined using the Boolean operator "or" and MeSH terms.

- Selection criteria:

1. Prospective or retrospective studies discussing treatment of infected Tibial nonunion

2. Journal articles, studies and papers are all involved.

3. Clinical studies within last 18 years.

- Exclusion criteria:

1. Non-human studies and case reports. $\underline{\mathbf{2}}$ Cadaveric studies

3. Reviews, Commentaries and general discussion papers not presenting data on impacts.

\section{- Statistical Analysis :}

The collected data will be presented as suitable tables and illustrated as suitable figures. Analysis of data will be with the aid of software package of SPSS using suitable statistical tests.

For all studies, patient selection, study inclusion and exclusion criteria, patient characteristics, procedure, protocol and outcomes measured were extracted using standardized data extraction forms.Outcomes were also extracted from each study. During data extraction, each 
included study was assessed for quality using the Cochrane Risk of Bias Checklist

\section{Results:}

318 abstracts were identified during the search, 10 were excluded, 308 full articles were fully reviewed, 295 articles were excluded, 13 studied matched the inclusion criteria and were included in this review, 2 additional articles were identified during searching (6-20), a total 652 patients of 15 studies were presented in this systemic review. (Table.1)

Table 1: Characteristics of included studies

\begin{tabular}{|c|c|c|c|c|c|c|c|}
\hline Study & Country & Intervention & Number & $\begin{array}{l}\text { Male: } \\
\text { female }\end{array}$ & $\begin{array}{l}\text { Age } \\
\text { range }\end{array}$ & $\mathrm{M} \pm \mathrm{SD}$ & Follow up \\
\hline $\begin{array}{l}\text { Bakhsh, K., et al. } \\
(2019)[6] \text {. }\end{array}$ & Pakistan & Ilizarov & 56 & $53: 3$. & $16-50$ & $32.58+1$ & $\begin{array}{l}8 \text { From } 7 \text { to } 36 \\
\text { months with a } \\
\text { mean of } 20 \\
\text { months. }\end{array}$ \\
\hline $\begin{array}{l}\text { Agrawal, A., et } \\
\text { al. (2018) [7]. }\end{array}$ & India & Ilizarov. & 16 & $12: 4$ & $\begin{array}{l}14 \text { patient } \\
\text { s }<40 \\
\text { years, } 2 \\
\text { patient } \\
\text { betwee n } \\
40-60 y\end{array}$ & NM & NM \\
\hline \multirow[t]{2}{*}{$\begin{array}{l}\text { Dujardyn,J. andJ. } \\
\text { Lammens (2007) [8]. }\end{array}$} & Belgium & $\begin{array}{l}\text { partial } \\
\text { fibulectomy }\end{array}$ & 28 & 21:7. & & & \\
\hline & & and Ilizarov & & & NM & NM & NM \\
\hline
\end{tabular}




\begin{tabular}{|c|c|c|c|c|c|c|c|}
\hline $\begin{array}{l}\text { Kayode,M. O., et } \\
\text { al. (2017) [9]. }\end{array}$ & $\begin{array}{l}\text { NIGERI } \\
\text { A }\end{array}$ & $\begin{array}{l}\text { Linear Rail- } \\
\text { fixator System } \\
\text { (LRS) } \\
\text { according to } \\
\text { Ilizarov } \\
\text { principle. }\end{array}$ & 30 & $17: 13$ & $4-57$ & 38 & $\begin{array}{l}\text { at least two } \\
\text { years }\end{array}$ \\
\hline $\begin{array}{l}\text { Khan, M. S., et al. } \\
(2015)[10] .\end{array}$ & Pakistan & $\begin{array}{l}\text { Ilizarov ring } \\
\text { fixation }\end{array}$ & 24 & $21: 3$ & $13-74$ & 38 & $\begin{array}{l}\text { Mean of } 11 \\
\text { (range, } 8-46) \\
\text { months }\end{array}$ \\
\hline $\begin{array}{l}\text { Li, W. Y., et al. } \\
\text { (2009) [11]. }\end{array}$ & China & $\begin{array}{l}\text { Antibiotic- } \\
\text { PMMA } \\
\text { combined with } \\
\text { external fixator. }\end{array}$ & 22 & $20: 2$ & $21-74$ & 34.68 & $\begin{array}{l}19.98 \\
\text { months } \\
\text { (ranging } 15 \\
\text { to } 28 \\
\text { months) }\end{array}$ \\
\hline $\begin{array}{l}\text { Madhusudhan, T. } \\
\text { R., et al. (2008) } \\
{[12] .}\end{array}$ & India & Ilizarov method & 22 & $18: 4$ & 37.2 & $20-52$ & $\begin{array}{l}13 \text { months } \\
\text { following } \\
\text { fracture } \\
\text { union. }\end{array}$ \\
\hline $\begin{array}{l}\text { Mahaluxmival a, J., } \\
\text { et al. (2005) [13]. }\end{array}$ & UK & $\begin{array}{l}\text { Ilizarov external } \\
\text { fixator }\end{array}$ & 18 & $16: 2$ & $\begin{array}{l}39.6 \\
\text { years }\end{array}$ & $\begin{array}{l}26 \text { to } 63 \\
\text { years }\end{array}$ & 18 months \\
\hline $\begin{array}{l}\text { Meleppuram, J. J. } \\
\text { and S. Ibrahim } \\
\text { (2017) [14]. }\end{array}$ & India & Ilizarov method & 42 & $32: 10$ & 38 years & $\begin{array}{l}26-64 \\
\text { years }\end{array}$ & $\begin{array}{l}14 \text { months } \\
\text { (range 10-24 } \\
\text { months }\end{array}$ \\
\hline $\begin{array}{l}\text { Rose,R.E.andW.S. } \\
\text { Palmer (2007) [15]. }\end{array}$ & Jamaica & $\begin{array}{l}\text { Ilizarov } \\
\text { Method }\end{array}$ & 8 & $7: 1$ & $17-53$. & 32 & $\begin{array}{l}\text { (range2-24 } \\
\text { months }\end{array}$ \\
\hline $\begin{array}{l}\text { Shahid, M., et al. } \\
\text { (2013) [16]. }\end{array}$ & UK & Ilizarov method & 12 & $10: 2$ & $28-89$ & 43.3 & $\begin{array}{l}\text { average } \\
62 \text { weeks } \\
(39-164)\end{array}$ \\
\hline $\begin{array}{l}\text { Wani, N. B. and B. } \\
\text { Syed (2015) [17]. }\end{array}$ & India & $\begin{array}{l}\text { Ilizarov ring } \\
\text { fixator }\end{array}$ & 26 & $22: 4$ & $20-65$ & 39 years & 1 year \\
\hline $\begin{array}{l}\text { Biasibetti, A., et al. } \\
\text { (2005) [18]. }\end{array}$ & Italy & $\begin{array}{l}\text { Mechanical } \\
\text { and biological } \\
\text { treatment } \\
\text { external fixation }\end{array}$ & $\begin{array}{l}172 \\
\text { tibia, }\end{array}$ & NM & $8-80$ & 32 years & NM \\
\hline $\begin{array}{l}\text { Yin, P., et al. (2015) } \\
\text { [19]. }\end{array}$ & China & bone transport & 110 & $92: 18$ & $\begin{array}{l}18-62 \\
\text { years }\end{array}$ & 38.90 & $\begin{array}{l}23.12 \\
\text { months (14- } \\
46 \text { months). }\end{array}$ \\
\hline $\begin{array}{l}\text { Yin, P., et al. } \\
\text { (2014)[20] }\end{array}$ & & Ilizarov method & 66 & $62: 4$ & 18 to62 & $\begin{array}{l}37.06 \\
\text { years }\end{array}$ & $\begin{array}{l}25.91 \\
\text { months } \\
(18-46 \\
\text { months }\end{array}$ \\
\hline
\end{tabular}

- The studies included are retrospective and prospective, Outcome measures were reported in most of the studies according to ASAMI score. This includes mainly bone results and functional outcome. Some papers reported further data.

- Study designs, study period and outcome measures are shown in Table.2. 
Table 2: Study design and outcome measures

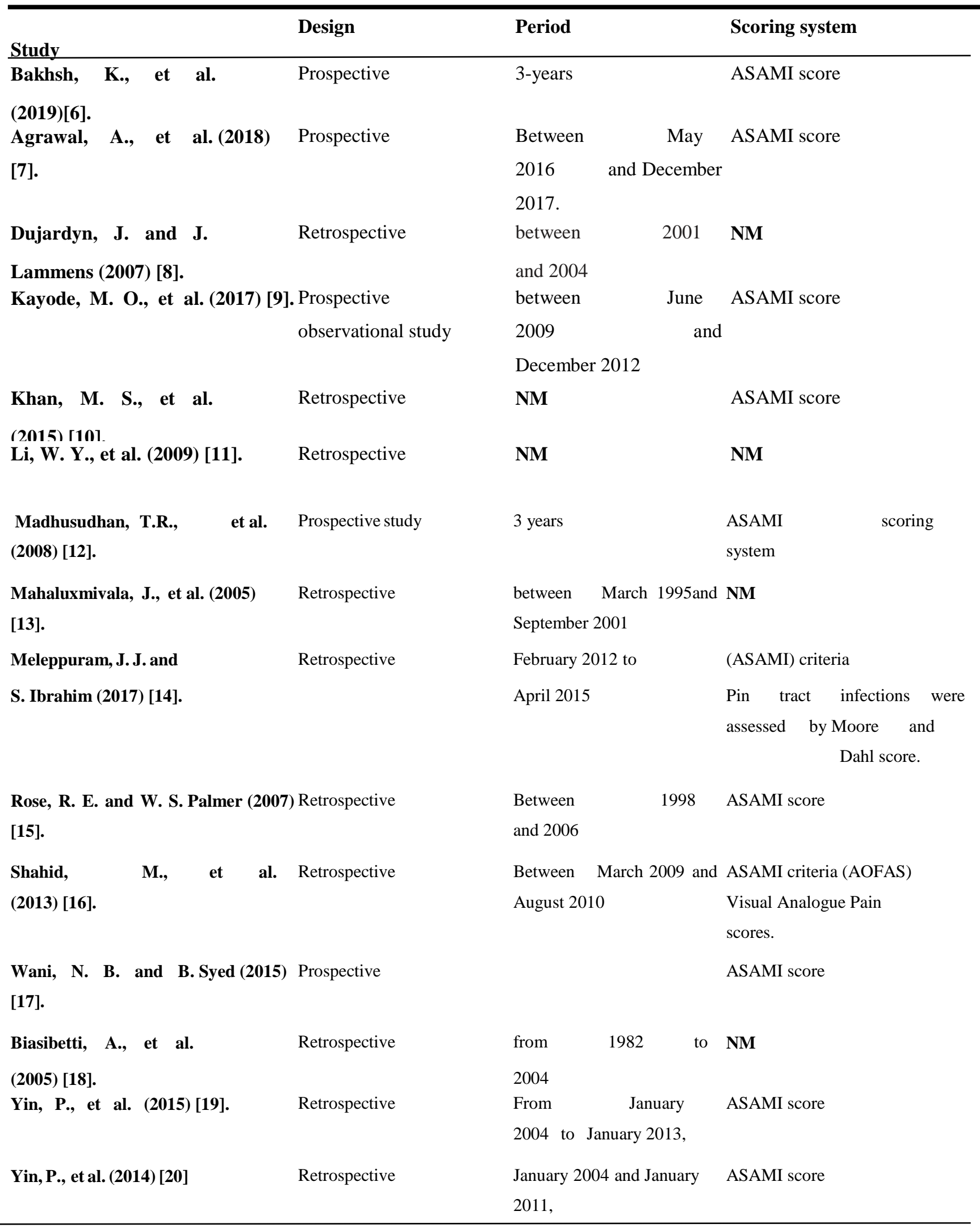


Benha medical journal vol. 38, special issue (orthopedic surgery), 2021

Regarding the type of bacteria causing the bone infection was not mentioned in studies by Agrawal, A., et al. (2018) (7), Dujardyn, J. and J. Lammens (2007) (8), Kayode, M. O., et al. (2017) (9). Li, W. Y., et al. (2009) (11), Mahaluxmivala, J., et al. (2005) (13), Rose, R. E. and W. S. Palmer (2007) (15) and Biasibetti, A., et al. (2005) (18). While Madhusudhan, T. R., et al. (2008) (12) reported mixed bacterial growth.(Table.3)

Table 3: Bacteria causing bone infection

\begin{tabular}{|c|c|c|c|c|c|c|c|c|c|c|c|}
\hline Study & & $\frac{\frac{\pi}{2}}{\frac{\pi}{\pi}}$ & 䓪 & & 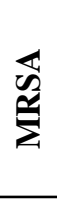 & 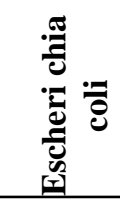 & 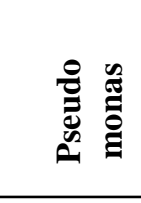 & 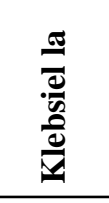 & 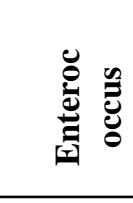 & $\frac{\grave{\Xi}}{\overline{0}}$ & 魚 \\
\hline $\begin{array}{l}\text { Bakhsh, } \\
\text { et } \\
(2019)[6]\end{array}$ & & 31 & & & 9 & 7 & 6 & 2 & 2 & 12 & 13 \\
\hline $\begin{array}{l}\text { Khan, M. S., } \\
\text { et al. (2015) } \\
{[10] .}\end{array}$ & 2 & & & 4 & & 1 & & & & & 9 \\
\hline $\begin{array}{l}\text { Meleppuram, } \\
\text { J. J. and S. } \\
\text { Ibrahim } \\
(2017)[14] \text {. }\end{array}$ & 28 & & 2 & & & & 6 & & & & \\
\hline $\begin{array}{l}\text { Shahid, M. } \\
\text { et al. }(2013 \\
{[16] .}\end{array}$ & 5 & & 1 & & & & 1 & & & 1 & \\
\hline $\begin{array}{l}\text { Wani, N. B. } \\
\text { and B. Syed } \\
(2015)[17] \text {. }\end{array}$ & 15 & & & & & 1 & 7 & 3 & & & 8 \\
\hline $\begin{array}{l}\text { Yin, P., et al. } \\
\text { (2015) [19]. }\end{array}$ & $51 \%$ & & & & & $18 \%$ & & $12 \%$ & $7 \%$ & $12 \%$ & \\
\hline $\begin{array}{l}\text { Yin, P., et al. } \\
(2014)[20]\end{array}$ & $47 \%$ & & & & & $13 \%$ & $16 \%$ & $9 \%$ & $6 \%$ & $9 \%$ & \\
\hline
\end{tabular}

Associated comorbidities were not mentioned in the majority of studies.(Table.4). Only Bakhsh, K., et al. (2019) (6) reported Smoking, Diabetes, malnourishment and obesity as associated comorbidities. 
Table 4: Associated comorbidities

\begin{tabular}{lllll}
\hline \multicolumn{1}{c}{ Smoking } & Diabetes & malnourished & Obese \\
$\begin{array}{l}\text { Study } \\
\text { Bakhsh, K., et al. (2019)[6]. 27(48.21\%). }\end{array}$ & $7(12.5 \%)$ & $9(16.07 \%)$ & $3(5.35 \%)$. \\
\hline
\end{tabular}

\section{Bone Results and Functional Results:}

- The criteria recommended by ASAMI were adopted to evaluate bone results and functional results in the studies $(6,7,10,12,14-17,19,20)$. Bone results were evaluated by 4 criteria: union, infection, deformity and limblength discrepancy. Functional results were evaluated by 5 criteria: active, limp, minimum stiffness (knee or ankle joint), reflex sympathetic dystrophy and pain.

- Bone results were evaluated in 12 studies by ASAMI $(6,7,10,12,14$ 17,19,20)Random effects meta-analysis showed that the weighted frequency of excellent rate, good rate, fair rate and poor rate in bone results were listed in Table 5.

\section{Bone results:}

Table 5: Bone results

\begin{tabular}{llllll}
\hline Study & N & Excellent & Good & Fair & Poor \\
\hline Bakhsh, K., et al. (2019)[6]. & 56 & 37 & 10 & 6 & 3 \\
Agrawal, A., et al. (2018) [7]. & 16 & 9 & 5 & 2 & 0 \\
Dujardyn, J. and J. Lammens (2007) [8]. & 28 & & & \\
Kayode, M. O., et al. (2017) [9]. & 30 & 7 & 20 & 0 & 3 \\
Khan, M. S., et al. (2015) [10]. & 24 & 6 & 14 & 1 & 2 \\
Li, W. Y., et al. (2009) [11]. & 22 & & & \\
Madhusudhan, T. R., et al. (2008) [12]. & 22 & 4 & 6 & 8 & 4 \\
Mahaluxmivala, J., et al. (2005) [13]. & 18 & & & & \\
Meleppuram, J. J. and S. Ibrahim (2017) [14]. & 42 & 25 & 6 & 11 & 0 \\
Rose, R. E. and W. S. Palmer (2007) [15]. & 8 & 1 & 3 & 1 & 3 \\
Shahid, M., et al. (2013) [16]. & 12 & 10 & 2 & 0 & 0 \\
Wani, N. B. and B. Syed (2015) [17]. & 26 & 13 & 9 & 4 & 0 \\
Yin, P., et al. (2015) [19]. & 110 & 68 & 28 & 12 & 2 \\
Yin, P., et al. (2014) [20] & 66 & 44 & 15 & 5 & 2 \\
\hline
\end{tabular}


Functional outcome:

Table 6: Functional outcome

\begin{tabular}{llllll}
\hline Study & N & excellent & good & fair & poor \\
\hline Bakhsh, K., et al. (2019) [6]. & 56 & 37 & 9 & 7 & 3 \\
Agrawal, A., et al. (2018) [7]. & 16 & 9 & 5 & 2 & 0 \\
Dujardyn, J. and J. Lammens (2007) [8]. & 28 & & & \\
Kayode, M. O., et al. (2017) [9]. & 30 & 8 & 19 & 0 & 3 \\
Khan, M. S., et al. (2015) [10]. & 24 & 8 & 12 & 2 & 1 \\
Li, W. Y., et al. (2009) [11]. & 22 & & & \\
Madhusudhan, T. R., et al. (2008) [12]. & 22 & 1 & 4 & 9 & 4 \\
Mahaluxmivala, J., et al. (2005) [13]. & 18 & & & \\
Meleppuram, J. J. and S. Ibrahim (2017) [14] & 42 & 23 & 12 & 2 & 4 \\
Rose, R. E. and W. S. Palmer (2007) [15]. & 8 & 1 & 3 & 0 & 2 \\
Shahid, M., et al. (2013) [16]. & 12 & 6 & 4 & 0 & 2 \\
Wani, N. B. and B. Syed (2015) [17]. & 26 & 9 & 11 & 5 & 1 \\
Biasibetti, A., et al. (2005) [18]. & 172 & & & & \\
Yin, P., et al. (2015) [19]. & 110 & 37 & 42 & 21 & 0 \\
Yin, P., et al. (2014) [20] & 66 & 24 & 26 & 10 & 0 \\
\hline
\end{tabular}

\section{Bone union:}

Table 7: outlines bone union in each study presented as Mean, Range and Rate.

\begin{tabular}{|c|c|c|c|}
\hline & Mean (weeks) & & \\
\hline Study & & Range & Rate \\
\hline Bakhsh, K., et al. (2019) [6]. & 10 & & $98.21 \%$ \\
\hline Agrawal, A., et al. (2018) [7]. & 10 & $40-140$ days & $100 \%$ \\
\hline Dujardyn, J. and J. Lammens (2007) [8]. & & & $96.4 \%$ \\
\hline Kayode, M. O., et al. (2017) [9]. & 24 & 3 to 11 & $95.45 \%$. \\
\hline Khan, M. S., et al. (2015) [10]. & 32 & $3-31 \mathrm{~m}$ & \\
\hline Li, W. Y., et al. (2009) [11]. & 15.09 & 8 to 24 weeks & $100 \%$ \\
\hline Madhusudhan, T. R., et al. (2008) [12]. & 37.2 & 6.5-13 Months & $81.82 \%$ \\
\hline Mahaluxmivala, J., et al. (2005) [13]. & 51.78 & $34.24-73.61$ & \\
\hline Meleppuram, J. J. and S. Ibrahim (2017) [14]. & & & $100 \%$ \\
\hline Rose, R. E. and W. S. Palmer (2007) [15]. & 21.4 & $2-9$ months & $75 \%$ \\
\hline Shahid, M., et al. (2013) [16]. & 46 & $(24-70)$ & $100 \%$ \\
\hline Wani, N. B. and B. Syed (2015) [17]. & & & $100 \%$ \\
\hline Biasibetti, A., et al. (2005) [18]. & 17.12 & $(2-6)$ & $93 \% \%$ \\
\hline Yin, P., et al. (2015) [19]. & 9.21 & (33 - 137 days) & $100 \%$ \\
\hline Yin, P., et al. (2014) [20] & 40.5 & (5.12-15.11 months) & $100 \%$ \\
\hline
\end{tabular}




\section{$\underline{\text { External fixation index : }}$}

The external fixation index denotes the number of days the external fixator is attached to the bone per centimetre of length gained. Using conventional Ilizarov fixation, this index is typically thirty days per centimetre of length gained.(Table.8); however, the rate differs based on variables such as patient age, osteotomy site and amount of lengthening $(20,21)$. In the selected studies, it was not reported in all. Ranged between 1.2 and $15.7(6,10)$.

Table.8:External fixation Index.

\begin{tabular}{lll}
\hline Study & Range (months/cm) & Mean (months/cm) \\
\hline Bakhsh, K., et al. (2019) [6]. & 1.2 to 1.6 & 1.40 \\
Agrawal, A., et al. (2018) [7]. & NM & NM \\
Dujardyn, J. and J. Lammens (2007) [8]. & NM & NM \\
Kayode, M. O., et al. (2017) [9]. & NM & NM \\
Khan, M. S., et al. (2015) [10]. & $1.5-15.7$ & 4.2 \\
Li, W. Y., et al. (2009) [11]. & & \\
Madhusudhan, T. R., et al. (2008) [12]. & NM & NM \\
Mahaluxmivala, J., et al. (2005) [13]. & NM & NM \\
Meleppuram, J. J. and S. Ibrahim (2017) [14]. & & 1.48 \\
Rose, R. E. and W. S. Palmer (2007) [15]. & NM & NM \\
Shahid, M., et al. (2013) [16]. & NM & NM \\
Wani, N. B. and B. Syed (2015) [17]. & $1.3-2$ & 1.6 \\
Biasibetti, A., et al. (2005) [18]. & NM & NM \\
Yin, P., et al. (2015) [19]. & $1.15-1.67$ & 1.48 \\
Yin, P., et al. (2014) [20]. & $1.15-1.58$ & 1.38 \\
\hline
\end{tabular}

\section{Complications :}

Pin site infection, knee stiffness, K-wires loosening, recurrence of wound infection, regenerate fracture, Malunion, paraesthesia, soft tissue impingement and Mortality was reported. Pin tract infection was the most common complication and it was managed by antibiotics in all studies. Mortality was reported in one case by Khan et al. (10).Complications are listed in (Table 9). 
Benha medical journal vol. 38, special issue (orthopedic surgery), 2021

Table 9: post-operative complications

Study
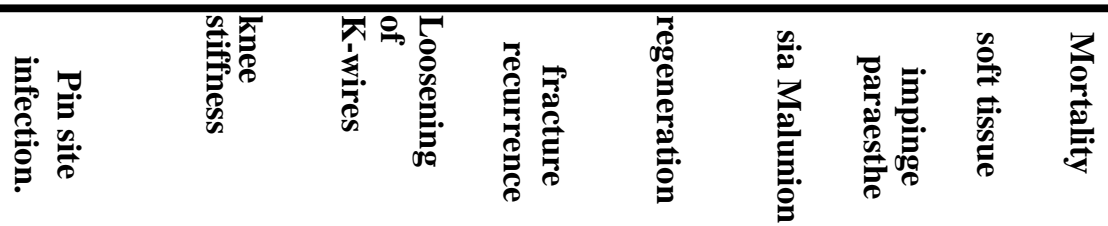

Bakhsh, K., et al. (2019) [6]. 27

2

7

1

16

1

$5 \quad$ No

Agrawal, A., et al. (2018) [7]. 10 Grade II,

No

4Grade III,

2 Grade IV

Dujardyn, J. and J. Lammens 1

(2007) [8].

Kayode, M. O., et al. (2017) 14 grades I,II 6

1

No

[9].

Khan, M. S., et al. (2015) [10]. 5

Li, W. Y., et al. (2009) [11].

Madhusudhan, T. R., et al. 22

7

(2008) [12].

Mahaluxmivala,[13] 4

Meleppuram, J. J. and 16 Grade II, 12

S. Ibrahim (2017) [14]. $\quad$ grade III 2 Grade

IV

Rose, R. E. and W. S. Palmer 8

(2007) [15].

Shahid, M., et al. (2013) [16]. 2

Wani, N. B. and B. 23

1

Syed (2015) [17].

Biasibetti, A., et al. (2005)[18].

Yin, P., et al. (2015) [19]. 46

Yin, P., et al. (2014) [20] 40

$\begin{array}{lll}4 & 2 & 20 \\ 4 & 2 & 19\end{array}$

According to Bakhsh et al., the associated soft tissue defects healed by soft tissue transport, VAC dressings and fasciocutaneous flaps [6]. 


\section{Meta analysis of bone results :}

Rate of excellent, good, fair and poor bone results are shown in table 10.

Table 10: meta analysis of bone results

\begin{tabular}{llllll}
\hline & & $\begin{array}{l}\text { Relevant } \\
\text { studies (n) }\end{array}$ & $\begin{array}{l}\text { Heterogenicit } \\
\mathbf{y}(\mathbf{P}, \mathbf{I 2}(\mathbf{\%}))\end{array}$ & ES (95 \% CI) & $\begin{array}{l}\text { Range of } \\
\text { incidence }\end{array}$ \\
\hline $\begin{array}{l}\text { Bone results } \\
\text { Rate of excellent results }\end{array}$ & 11 & $<0.001,98 \%$ & $0.435(0.210,0.660)$ & $12.5-66.5 \%$ \\
$\begin{array}{l}\text { Rate of } \\
\text { results }\end{array}$ & good & 10 & $<0.001,76 \%$ & $0.307(0.216,0.398)$ & $14.3-66.7 \%$ \\
$\begin{array}{l}\text { Rate of } \\
\text { results } \\
\text { Rate of }\end{array}$ & fair & 8 & $0.002,63 \%$ & $0.102(0.056,0.149)$ & $0-36.4 \%$ \\
poor & 7 & $0.237,22 \%$ & $0.031(0.012$, & $0-37.5 \%$ \\
\hline
\end{tabular}

\section{Meta analysis of functional results :}

Table 11: Meta analysis of functional results

\begin{tabular}{|c|c|c|c|c|}
\hline Bone results & $\begin{array}{l}\text { Relevant } \\
\text { studies (n) }\end{array}$ & $\begin{array}{l}\text { Heterogenicity (P, I2 } \\
(\%)\end{array}$ & $\begin{array}{l}\text { ES }(95 \% \\
\text { CI })\end{array}$ & $\begin{array}{l}\text { Range of } \\
\text { incidence }\end{array}$ \\
\hline $\begin{array}{l}\text { Rate of } \\
\text { excellent results }\end{array}$ & 11 & $<0.00188 \%$ & $0.367(0.240,0.495)$ & $12.5-66.1 \%$ \\
\hline Rate of good results & 11 & $<0.00170 \%$ & $0.355(0.268,0.442)$ & $16.1-63.3 \%$ \\
\hline Rate of fair & 8 & $<0.00171 \%$ & $0.113(0.060$ & $0-40.9 \%$ \\
\hline results & & & $0.166)$ & \\
\hline Rate of poor results & 7 & $0.036,48 \%$ & $\begin{array}{l}0.034 \\
(0.010,0.058)\end{array}$ & $0-25 \%$ \\
\hline
\end{tabular}

\section{Meta analysis of complications}

Table 12: Meta analysis of complications

\begin{tabular}{|c|c|c|c|c|}
\hline Complication & $\begin{array}{l}\text { Relevant } \\
\text { studies (n) }\end{array}$ & $\begin{array}{l}\text { Heterogenicity (P, I2 } \\
(\%)\end{array}$ & ES $(95 \%$ CI $)$ & $\begin{array}{l}\text { Range of } \\
\text { incidence }\end{array}$ \\
\hline Pin site infection. & 13 & $<0.001,98 \%$ & $0.549(0.333,0.764)$ & $3.6-100 \%$ \\
\hline knee stiffness & 3 & $<0.00196 \%$ & $\begin{array}{l}0.285(-0.003 \\
0.573)\end{array}$ & $3.6-30.8 \%$ \\
\hline K-wires loosening & 6 & $0.05254 \%$ & $0.074(0.027,0.121)$ & $3.6-31.8 \%$ \\
\hline $\begin{array}{l}\text { Recurrence of wound } \\
\text { infection }\end{array}$ & 6 & $0.35410 \%$ & $0.042(0.013,0.070)$ & $1.8-18.2 \%$ \\
\hline Regenerate fracture & 7 & $0.7000 \%$ & $0.026(0.009,0.042)$ & $1.8-10.7 \%$ \\
\hline Malunion & 4 & $0.00280 \%$ & $0.150(0.057,0.243)$ & $4.2-28.8 \%$ \\
\hline
\end{tabular}


Forest plot below shows the proportion of pin site infection in every study.
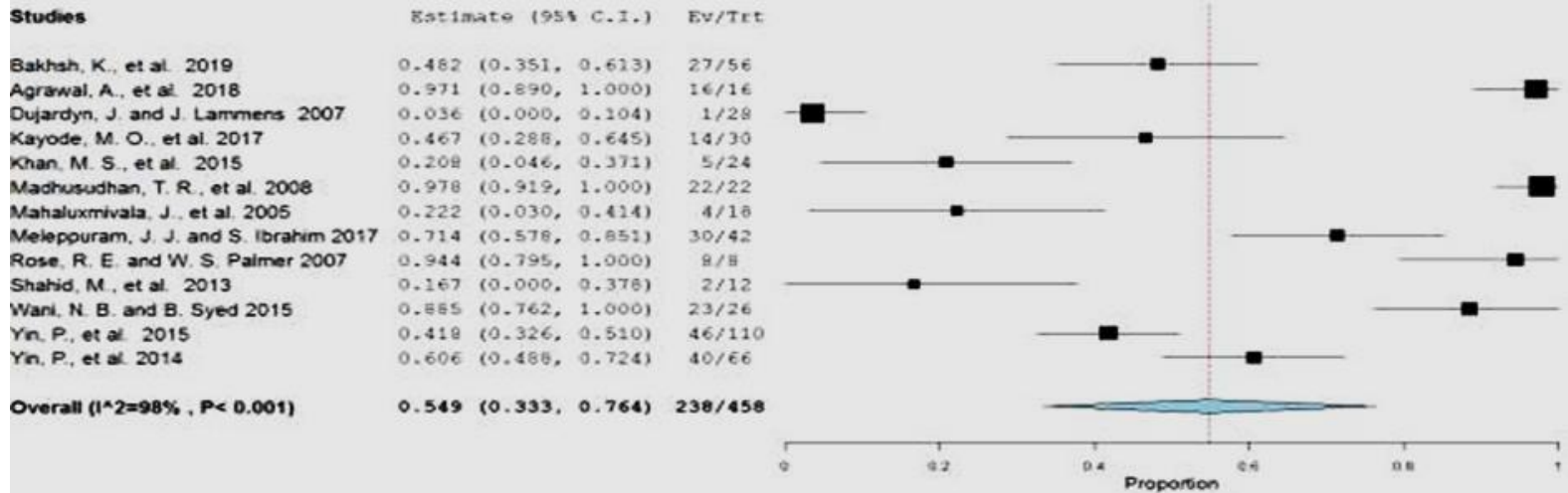

\section{Discussion:}

Infected non-union of the tibia is still challenging, especially with presence of bone and soft tissue defect, it was proved that Ilizarov external fixator show a high rate of success in the treatment of such difficult cases.(20)

Debridment of devitalized bone and soft tissue, antibiotic therapy and antibiotic impregnated beads can lead to acceptable cure rate in less virulence infection, while in sever type of bone infection radical debridment, stable external fixator and bone transport or compression distraction are mandatory to gain bone union. $(21,22)$

Papineau technique, tibiofibular synostosis, other bone substitutes is of limited ability to reconstruct the limb length discrepancy and to correct the limb deformity. (22) in addition to lack of limb movement. (23)

Ilizarov and his follows since 1950 have employed new biological techniques and a different system of external fixation to achieve union, correct deformity eradicate infection, limb length restoration, in association of maintaining of limb function. $(22,23)$

Ilizarov apparatus is a very good tool to treat large bone defects due to radical debridment in infected nonunion $(22,23)$. It can be done either by trifocal osteosynthesis or bifocal osteosynthesis, or by gradual fibular transfer (24). 
This is a systematic review of the treatment of infected nonunion of tibia. The majority of the studies used Ilizarov method. This systematic review included 15 studies, and we conducted a meta-analysis of 11 studies to evaluate the efficacy of fixation method in the treatment of infected nonunion of tibia. The poor rate in bone results and functional results was $4.6 \%(95 \% \mathrm{CI}, 0.012$, $0.051 ; \mathrm{I} 2=22 \%, \mathrm{P}=0.237)$ and $4.9 \%$ (95\%CI, 0.057, 0.243; I2 = 80\%, P = 0.002). The data were not statistically heterogeneous. So, these results showed that the patients with infected nonunion of tibia treated by Ilizarov methods had a low rate of poor bone and functional results.

We did a meta-analysis of complication in patients with infected nonunion of tibia treated by Ilizarov method. Statistically homogeneity was found in most of the complications (Table 12). Pin-track infection is the most common complication by using Ilizarov methods, and significant statistically heterogeneity was found in the complication.

The rate of pin-track infection was 3.6$100 \%$ among included studies in our systematic review. Hence, we considered that careful pin care was the key to reducing the complication.
The data of infected tibia nonunion could be found in Table 5 and Table 6. The poor rate in bone results and functional results was was $4.6 \%(95 \% \mathrm{CI}, 0.012,0.051$; I2 = 22\%, $\mathrm{P}=0.237)$ and $4.9 \%$ (95\%CI, 0.057, 0.243; $\mathrm{I} 2=80 \%, \mathrm{P}=0.002)$.

The rate of Pin site infection, knee stiffness, K-wires loosening, recurrence of wound infection, regenerate fracture, Malunion, paraesthesia soft tissue impingement and Mortality were respectively $36.50 \%, 2.45 \%$, $3.68 \%, 1.38 \%, 1.84 \%, 7.06 \%, 0.15 \%, 1.07 \%$ and $0.15 \%$. These data were not statistically heterogeneous.

We also conducted meta-analyses of bone and functional results in our systematic review. High heterogeneity existed in several pooling data in our study, and we thought the heterogeneity was probably resulted from the different research quality, various surgeons' experience and diversity of rehabilitation nursing.

Failure to include the non-English language studies in our article could have resulted in missing data and our estimates of effect size might have been biased, nevertheless, 15 studies were included in our article and they were not excessively affected by significant statistical heterogeneity. The data of the present review were extracted from observational studies, which are likely to 
cause both systematic and random errors. Therefore, more prospective randomized controlled trials are needed to overcome the limitation of this study.

\section{Conclusion:}

In conclusion, our systematic review showed that the patients with infected nonunion of tibia treated by Ilizarov methods had a low rate of poor bone and functional results. Therefore, Ilizarov methods may be a good choice for the treatment of infected nonunion of tibia .

\section{References :}

1. Phieffer LS, Goulet JA.Delayed unions of the tibia. J Bone Joint Surg Am2006 88:205-216.

2. Fenton P, Bose D: Patient-reported outcomes following treatment of tibial non-union with circular frames. Strategies in Trauma and Limb Reconstruction2014 ; 9: 33-35.

3. Deng Z, Cai L, Jin W, Ping A, Wei R . Onestage reconstruction with open bone grafting and vacuum-assisted closure for infected tibial non-union. Arch Med Sci.2014; 29; 10(4): 764 772.

4. Said G, El-Sharkawi M, Said H, Refai OA: Fibula-pro-tibia in plating tibial non-unions. International Orthopaedics2011; 35:1713-1718.

5. Salih S, Blakey C,Chan D, McGregor-Riley J C , Royston S L, Gowlett S , Moore D, Dennison M G. The callus fracture sign: a radiological predictor of progression to hypertrophic non-union in diaphyseal tibial fractures. Strategies in Trauma and Limb Reconstruction2015; 10, Issue 3:149-15.
6- Bakhsh K, Atiq-Ur-Rehman FK, Mohammad E, Ahmed W, Saaiq M., Presentation and management outcome of tibial infected non-union with Ilizarov technique. Pak J Med Sci. 2019; 35(1): 136-140.

7- Agrawal, A., H. Sakale, and B. Kar, Management of infected nonunion of tibia by Ilizarov technique. Journal of Orthopedics, Traumatology and Rehabilitation 2018; 10 (1): p. 1.

8- Dujardyn, J. and J. Lammens. Treatment of delayed union or non-union of the tibial shaft with partial fibulectomy and an Ilizarov frame. Acta Orthop Belg 2007 73(5): 630-4.

9- MO, K., OA, A., MO, S. and SO, G.experience with managing complicated fractures using Ilizarov principals in Lagos, Nigeria. J West Afr Coll Surg 2017; 7(3): 24-43.

10- Khan MS, Rashid H, Umer M, Qadir I, Hafeez $\mathrm{K}$, Iqbal A.Salvage of infected non-union of the tibia with an Ilizarov ring fixator. J Orthop Surg (Hong Kong) 2015; 23(1): 52-5.

11- Li WY, Zhang BS, Zhang L, Zheng W, Zheng SH, Dai D, Wang SM.,[AntibioticPMMAbeadscombined with external fixator for treating the infected fracture nonunion]. Zhongguo Gu Shang 2009; 22(2): 90-2.

12- Madhusudhan TR, Ramesh B, Manjunath KS, Shah HM, Sundaresh DC, Krishnappa N. Outcomes of Ilizarov ring fixation in recalcitrant infected tibial non-unions - a prospective study. J Trauma Manag Outcomes 2008;2(1): p. 6.

13 Mahaluxmivala J, Nadarajah R, Allen PW, Hill RA. Ilizarov external fixator: acute shortening and 
lengthening versus bone transport in the management of tibial non-unions. Injury 2005; 36(5): 662-8.

14- Meleppuram, J.J. and S. Ibrahim. Experience in fixation of infected non-union tibia by Ilizarov technique - a retrospective study of 42 cases. Rev Bras Ortop 2017; 52(6): 670-675.

15- Rose, R.E. and W.S. Palmer. The Illizarov method in infected non-union of long bones. West Indian Med J 2007;56(3): 246-51.

16- Shahid M, Hussain A, Bridgeman P, Bose D. Clinical outcomes of the Ilizarov method after an infected tibial non union. Arch Trauma Res 2013;2(2):71-5.

17- Wani, N.B. and B. Syed. Ilizarov ring fixator in the management of infected non-unions of tibia. Sicot j 2015; 1: p. 22.

18- Biasibetti A, Aloj D, Di Gregorio G, Massè A, Salomone C. Mechanical and biological treatment of long bone non-unions. Injury 2005; 36 Suppl 4: S45-50.

19- Yin P, Zhang L, Li T, Zhang L, Wang G, Li J, Liu J, Zhou J, Zhang Q, Tang P.Infected nonunion of tibia and femur treated by bone transport, in $\mathbf{J}$ Orthop Surg Res 2015; 49.

20- Yin P, Zhang Q, Mao Z, Li T, Zhang L, Tang

P. The treatment of infected tibial nonunion by bone transport using the Ilizarov external fixator and a systematic review of infected tibial nonunion treated by Ilizarov methods. Acta Orthop Belg 2014; 80(3):426-35.

21- Arora S, Batra S, Gupta V, Goyal A. Distraction osteogenesis using a monolateral external fixator for infected nonunion of the femur with bone loss. Journal of orthopaedic surgery 2012; 20(2): 185-190.

22- Samanta AK, Ghosh S, Chaudhuri A, Mondal SC. Ilizarov ring fixator in treatment of infected nonunion of tibia. Saudi Journal of Sports Medicine 2016; 16(2): 159-161.

23- McKee MD, DiPasquale DJ, Wild LM, Stephen DJ, Kreder HJ, Schemitsch EH. The effect of smoking on clinical outcome and complication rates following Ilizarov reconstruction. Journal of orthopaedic trauma 2003; 17(10): 663-667.

24- Meselhy M.A.,M.Singer, Halawa.A, Hosny G.A.,Adawy H.A., Essawy M.O.Gradual fibular transfer by Ilizarov external fixator in post-traumatic and postinfection large tibial bone defect.Archives of orthop.and trauma surg 2018;138:653-660.

To cite this article: Gamal A. Hosny, Mohamed A. Moselhy, Adel S. ElHamady, Peter M. Zaky Abadir. A Systematic Review and Meta-Analysis of Treatment of Infected Tibial non Union. BMFJ 2021; 38 (orthopedic surgery): 45-59. DOI: 10.21608/bmfj.2021.16742.1051 